\title{
The Caenorhabditis elegans cell-death protein CED-3 is a cysteine protease with substrate specificities similar to those of the human CPP32 protease
}

\author{
Ding Xue, Shai Shaham, and H. Robert Horvitz \\ Howard Hughes Medical Institute, Department of Biology, 68-425, Massachusetts Institute of Technology, Cambridge,
} Massachusetts 02139 USA

The Caenorhabditis elegans cell-death gene ced-3 encodes a protein similar to mammalian interleukin-1ß-converting enzyme (ICE), a cysteine protease implicated in mammalian apoptosis. We show that the full-length CED-3 protein undergoes proteolytic activation to generate a CED-3 cysteine protease and that CED-3 protease activity is required for killing cells by programmed cell death in $C$. elegans. We developed an easy and general method for the purification of CED-3/ICE-like proteases and used this method to facilitate a comparison of the substrate specificities of four different purified cysteine proteases. We found that in its substrate preferences CED-3 was more similar to the mammalian CPP32 protease than to mammalian ICE or NEDD2/ICH-1 protease. Our results suggest that different mammalian CED-3/ICE-like proteases may have distinct roles in mammalian apoptosis and that CPP32 is a candidate for being a mammalian functional equivalent of CED-3.

[Key Words: Programmed cell death; cysteine proteases; ced-3; C. elegans; substrate specificities]

Received February 28, 1996; revised version accepted March 19, 1996

Programmed cell death is a fundamental cellular process in the development and homeostasis of both vertebrates and invertebrates (Ellis et al. 1991; Steller 1995). The misregulation of cell death can lead to human disease (for review, see Thompson 1995), and the mechanisms that initiate and execute the cell death program have been the focus of intense studies (for review, see Horvitz et al. 1994; Oltvai and Korsmeyer 1994; Martin and Green 1995).

Genetic analysis of the nematode Caenorhabditis elegans has identified two genes, ced-3 and ced-4, required for programmed cell death in this organism (Ellis and Horvitz 1986). In ced-3 and ced-4 mutant animals, cells that normally undergo programmed cell death instead survive. ced-4 encodes a protein with a novel sequence (Yuan and Horvitz 1992). ced-3 encodes a protein similar to mammalian interleukin-1 $\beta$ (IL-1 $\beta$ )-converting enzyme (ICE) (Yuan et al. 1993). ICE is a highly specific cysteine protease that cleaves the $31-\mathrm{kD}$ IL- $1 \beta$ precursor at two aspartic acid residues to produce the $17.5 \mathrm{kD}$ mature cytokine (Cerretti et al. 1992; Thomberry et al. 1992). Active ICE comprises a heterodimer of a $10-\mathrm{kD}$ $(\mathrm{p} 10)$ and a $20-\mathrm{kD}(\mathrm{p} 20)$ subunit, both of which derive by proteolysis from a $45-\mathrm{kD}$ ICE proenzyme (Thornberry et al. 1992). Studies of the crystal structure of ICE suggest that it may exist as a $(\mathrm{p} 10 / \mathrm{p} 20)_{2}$ tetramer (Walker et al. 1994; Wilson et al. 1994). The sequence similarity be- tween ICE and CED-3 suggested that CED-3 may act as a protease to cause programmed cell death in C. elegans (Yuan et al. 1993).

Recently, six additional mammalian proteins (NEDD2/ICH-1, CPP32/Yama/apopain, TX/ICH-2/ICE ${ }_{\text {rel II, }}$ ICE $_{\mathrm{rel}}$ III, $\mathrm{MCH}-2$, and $\mathrm{MCH} \cdot 3$ ) have been identified with sequence similarities to both CED-3 and ICE (FernandesAlnemri et al. 1994, 1995a,b; Kumar et al. 1994; Wang et al. 1994; Faucheu et al. 1995; Kamens et al. 1995; Munday et al. 1995; Nicholson et al. 1995; Tewari et al. 19951. Overexpression of any of these proteins in mammalian cells can initiate apoptotic cell death, suggesting that these proteins have functional similarities to CED3. Furthermore, the baculovirus $\mathrm{p} 35$ protein, which inhibits the activities of the CED-3/ICE family of proteases (Bump et al. 1995; Xue and Horvitz 1995), blocks programmed cell death in diverse species (Clem et al. 1991; Kamita et al. 1993; Rabizadeh et al. 1993; Hay et al. 1994; Sugimoto et al. 1994). These observations suggest that members of the CED-3/ICE cysteine protease family may be involved in killing cells by programmed cell death in many different species.

Because different CED-3/ICE-like mammalian cysteine proteases are coexpressed in many tissues and cell types (Fernandes-Alnemri et al. 1994, 1995a,b; Kumar et al. 1994; Wang et al. 1994; Faucheu et al. 1995; Munday et al. 1995; Nicholson et al. 1995; Tewari et al. 1995), 
these proteases may overlap in their functions and/or regulate each other's activities. The observation that ICE-deficient mice are grossly normal and show defects only in Fas-mediated thymocyte apoptosis (Li et al. 1995; Kuida et al. 1995) suggests either that there are redundant cell-death pathways in mammals or that ICE plays little or no role in apoptosis in vivo. Two recent reports suggest that the human CPP32/Yama/apopain protein (which we will refer to as CPP32) is directly involved in mammalian apoptosis (Nicholson et al. 1995; Tewari et al. 1995). In these studies CPP32 was shown to be a cysteine protease that can cleave the $113-\mathrm{kD}$ poly(ADP-ribose) polymerase (PARP) to generate an $89-\mathrm{kD}$ fragment (Nicholson et al. 1995; Tewari et al. 1995). Such cleavage of PARP occurs concomitantly with the onset of apoptosis (Kaufmann et al. 1993; Lazebnik et al. 1994). In addition, a potent peptide aldehyde inhibitor of the CPP32 protease (Acetyl-Asp-Glu-Val-Asp-CHO) prevented in vitro-reconstituted apoptotic events, whereas a potent peptide aldehyde inhibitor of the ICE protease (acetyl-Tyr-Val-Ala-Asp-CHO) failed to do so (Nicholson et al. 1995). These observations suggest but do not establish that CPP32 functions directly in mammalian apoptosis.

To assess the roles of mammalian CED-3/ICE-like proteases in apoptosis as well as the possible regulatory interactions among these proteases, we initiated a biochemical characterization of the CED-3, ICE, NEDD2/ $\mathrm{ICH}-1$ / which we will refer to as ICH-1, because we studied the human clonel, and CPP32 proteins and compared the biochemical properties of the CED-3 protease with those of the ICE, ICH-1, and CPP32 proteases.

\section{Results}

\section{CED-3 is a cysteine protease}

To determine whether the full-length CED-3 protein is proteolytically activated in a manner similar to ICE /Molineaux et al. 1993), we tagged the CED-3 protein with the FLAG octapeptide (DYKDDDDK, single-amino acid code; Hopp et al. 1988/ at its carboxyl terminus and expressed this tagged protein under the control of the T7 promoter in Escherichia coli. Western blot analysis of bacterial lysates using the M2 monoclonal antibody to recognize the FLAG peptide detected three protein products of 32,15 , and $13 \mathrm{kD}$ (Fig. 1A), all of which are smaller than the full-length 56-kD CED-3-FLAG protein (Fig. 1A; Yuan et al. 1993). All three proteins were CED3-FLAG-specific, as they were not seen in lysates of bacteria carrying only the expression vector pET-3a. All three proteins were also absent in lysates of bacteria expressing a mutated CED-3-FLAG protein in which the presumptive active-site cysteine was replaced by a serine (C358S; Yuan et al. 1993); instead, a 56-kD protein was detected. These results suggest that the $56-\mathrm{kD}$ fulllength CED-3-FLAG protein underwent a CED-3-dependent proteolysis in $E$. coli to generate three overlapping carboxy-terminal cleavage products of 32,15 , and $13 \mathrm{kD}$.

To determine whether the CED-3-FLAG protein produced and processed in $E$. coli could act as a protease in vitro, we incubated $\left[{ }^{35} \mathrm{~S}\right]$ methionine-labeled full-length CED-3 protein synthesized in vitro using rabbit reticulocyte lysates with bacterial lysates expressing the CED3-FLAG protein. Multiple cleavage products were generated (Fig. 1B). In contrast, lysates from bacteria that had expressed mutant CED-3(C358S)-FLAG protein had no such activity. Like the cysteine protease activities of ICE and CPP32, CED-3 protease activity was inhibited by the cysteine-alkylating reagent iodoacetic acid but not by the cysteine protease inhibitor $N-[N-(\mathrm{L}-3-$ transcarboxirane-2-carbonyl--leucyl)-agmatine (E-64) or by the serine and cysteine protease inhibitor L-1-chloro-3-[4-tosylamido)-7-amino-2-heptanone (TLCK) (Fig. 1B; Thornberry et al. 1992; Nicholson et al. 1995). Other protease inhibitors, L-1-chloro-3-[4-tosylamido]-4-phenyl-2-butanone (TPCK), phenylmethylsulfonyl fluoride (PMSF), leupeptin, aprotinin, and pepstatin (Thornberry et al. 1992; Nicholson et al. 1995), also failed to inhibit CED-3 protease activity (data not shown).

These observations strongly suggest that CED-3 is a cysteine protease similar to ICE.

In vivo cell-killing activities of mutant CED-3 proteins correlate with their in vitro protease activities

Our finding that the CED-3(C358S) mutant protein lacks protease activity combined with our finding that this mutant protein fails to cause programmed cell death in vivo (S. Shaham and H.R. Horvitz, in prep.) supports the hypothesis that CED-3 protease activity is essential for the ability of CED-3 to cause programmed cell death. To explore this hypothesis further, we determined both the extents of the proteolytic processing in bacteria and the in vitro protease activities of the CED-3 proteins derived from three additional mutant ced-3 alleles: n2427(G474R), n1129(A449V), and n2433(G360S) (Yuan et al. 1993). We found that animals homozygous for these ced-3 alleles have reduced, very low, and possibly no ced-3 activity in vivo, respectively, as assayed (Hengartner et al. 1992) by counting the number of extra or "undead" cells in the anterior pharynx of mutant animals (with an average of 1.2, 8.7, and 12.4 extra cells, respectively). We expressed these three mutant CED-3 proteins as well as the wild-type CED-3 and CED-3(C358S) proteins in E. coli. These three mutant CED-3 proteins appeared to be differentially defective in proteolytic processing in $E$. coli and in protease activity in vitro: CED-3(G474R) was almost completely processed, CED3(A449V) was partially processed, and CED-3(G360S) was not processed (Fig. 2A,C). Similarly, these three mutant CED-3 proteins showed protease activities close to wild-type (G474R), weak (A449V), and nondetectable (G360S), respectively (Fig. 2B). Thus, in both assays, the in vivo cell-killing activities of mutant CED-3 proteins correlated with their in vitro protease activities. These results suggest that $C E D-3$ protease activity is crucial for its role in programmed cell death in C. elegans.

\section{Purification of active CED-3/ICE cysteine proteases}

We developed an easy and general method for purifying 
A
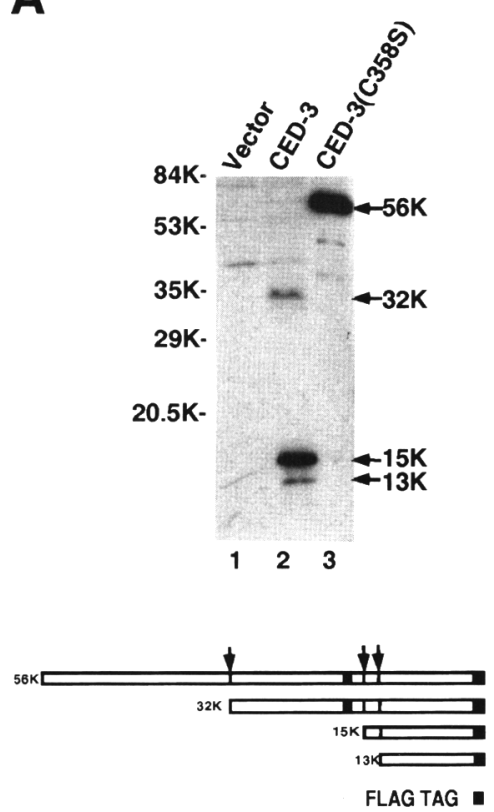

B
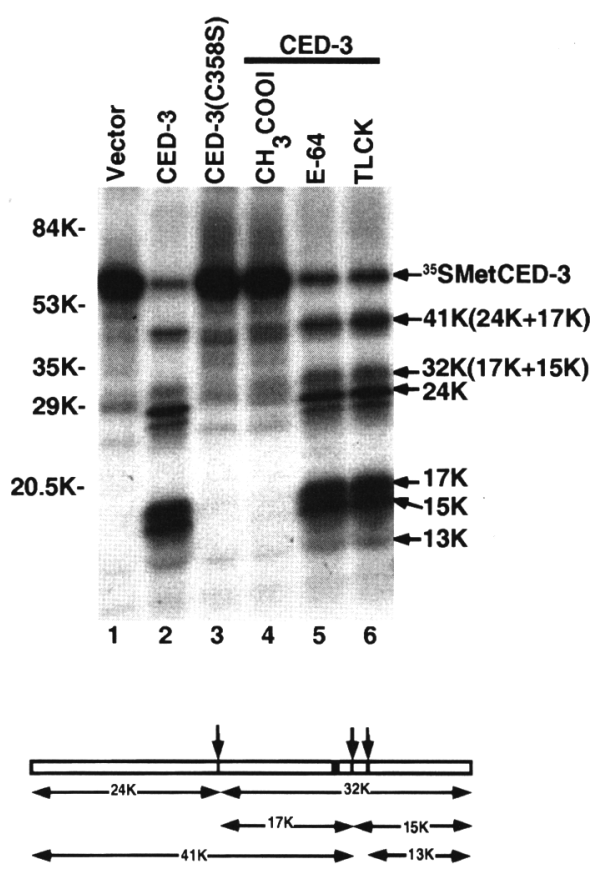

Figure 1. CED-3 is processed in E. coli to generate a cysteine protease. $|A|$ Western blot analysis of the cleavage of CED-3 in $E$. coli. Bacteria containing either expression vector pET-3a alone (Vector, lane 1), pET-3a-CED-3-FLAG (lane 2), or pET-3a-CED-3|C358S) FLAG (lane 3) were lysed by sonication, and $1 \mu \mathrm{g}$ of proteins from the lysates were resolved by electrophoresis on a $15 \%$ SDSpolyacrylamide gel, transferred to a nitrocellulose membrane, and detected with mouse M2 monoclonal antibody (Eastman Kodak), which recognizes the FLAG epitope. The diagram depicts the deduced origins of the detected protein bands as determined by microsequencing analysis (see Fig. 3). Solid boxes indicate FLAG tags; shaded boxes indicate the absolutely conserved pentapeptide sequence (QACRG) around the active-site cysteine in members of the ICE/CED-3 cysteine protease family. Vertical arrows indicate proteolytic cleavage sites. Protein sizes are indicated. $|B|$ In vitro protease assays with wild-type or mutant CED-3 bacterial lysates and with protease inhibitors. One microliter of $\left[{ }^{35} S \mid\right.$ methionine-labeled CED-3 precursor (see Materials and methods) was incubated for 1 hr at $30^{\circ} \mathrm{C}$ with $4 \mu \mathrm{g}$ of lysates from bacteria transformed with the following expression vectors. (Lane 1) pET-3a (Vector); (lane 2) pET-3a-CED-3-FLAG; (lane 3) pET-3a-CED-3|C358S)-FLAG; (lanes 4-6) pET-3a-CED-3-FLAG in the presence of iodoacetic acid (5 $\mathrm{mM}$, lane 4), E-64 (0.2 $\mathrm{mm}$, lane 5), and TLCK $10.2 \mathrm{~mm}$, lane 6). The diagram depicts the deduced origins of the cleavage products (see Fig. 3). Vertical arrows indicate cleavage sites. The shaded box indicates the QACRG pentapeptide. Protein sizes are indicated. The CED-3 precursor synthesized in rabbit reticulocyte lysates was not processed as it is in E. coli or as reported by Hugunin et al. (1996), possibly because the level of CED-3 expression was not sufficient to initiate proteolytic processing.

CED-3/ICE family cysteine proteases from bacteria using epitope tagging. Because active ICE is likely to exist as a tightly associated tetramer complex (Walker et al. 1994; Wilson et al. 1994), we reasoned that epitope-tagging one subunit of a CED-3/ICE-like protease would allow us to purify the entire protease complex with an antibody or affinity resin that binds the epitope tag. We tagged full-length CED-3, human ICH-1 (hICH-1), human CPP32, and a truncated version of murine ICE (mICE) (amino acids 118-402; Molineaux et al. 1993) at their carboxyl termini with either a FLAG epitope, a 6-histidine peptide, or both (see Materials and methods) and expressed these tagged proteins in $E$. coli using the pET-3a protein expression vector (Studier et al. 1990).

When expressed in E. coli, each of the three mammalian proteins underwent proteolytic processing similar to that of CED-3 to generate a cysteine protease /data not shown). We purified all four protease activities to apparent homogeneity using a combination of ion-exchange and affinity chromatography (Fig. 3A; see Materials and methods). We subjected the purified proteases to electro- phoresis using $15 \%$ polyacrylamide-SDS gels and determined the amino-terminal sequences of the major polypeptides present in each protease preparation by $\mathrm{mi}$ crosequencing analysis.

As shown in Figure 3, the 19.5- and 10-kD polypeptides present in the purified mICE protease preparation were products resulting from cleavage of the truncated ICE protein at Asp-122 and Asp-314. These polypeptides correspond to the p20 and p10 subunits of hICE described by Thornberry et al. (1992). The p20 subunit of hICE has four additional amino acids at its amino terminus as a consequence of cleavage at Asp-119 !amino acid 123 in hICE, which is equivalent to amino acid 122 in mICE, is not an Asp residue; Thronberry et al. 1992). The 20-kD mICE polypeptide had six additional amino acids (MQNKED) that extended from the amino terminus of the $19.5-\mathrm{kD}$ polypeptide, a result of the failure of cleavage at Asp-122 and the inclusion of the Met residue used to initiate translation in E. coli (Fig. 3; Molineaux et al. 1993). Our purified active mICE had similar subunit composition (20- and 10-kD polypeptides) and compara- 
Figure 2. The in vivo cell-killing activities of CED-3 mutant proteins correlate with their in vitro protease activities. $(A)$ Cleavage of wild-type and mutant CED-3 proteins in E. coli. Bacterial lysates containing the expression vectors indicated below were used for Western blot analysis as described in Fig. 1A. The amount of total protein used from each lysate is indicated as follows: (Lane 1) pET-3a (1 $\mu \mathrm{g})$; (lane 2) pET-3a-CED-3-FLAG $(1 \mu \mathrm{g})$; (lane 3) pET3a-CED-3(G474R)-FLAG (1 $\mu g$ ); (lane 4) pET-3a-CED-3(A449V)-FLAG (1 $\mu \mathrm{g})$; (lane 5) pET-3a-CED-3(G360S)-FLAG $(0.1 \mu \mathrm{g})$; (lane 6) pET-3a-CED-3(C358S)-FLAG 10.2 $\mu \mathrm{g})$. Because CED-3(G360S/-FLAG and CED-3|C358S|-FLAG lysates had much higher total CED-3 protein levels than the other lysates, less total protein was used for the experiments shown in lanes 5 and $6 .(B)$ In vitro protease assays with CED- 3 wildtype or mutant bacterial lysates. One microliter of $\left[{ }^{35} \mathrm{~S}\right]$ methionine-labeled CED-3 precursor protein was incubated with identical amounts of CED-3 wild-type or mutant bacterial lysates used in $A$ at $30^{\circ} \mathrm{C}$ for $20 \mathrm{~min}$. Two additional sets of experiments with independently prepared lysates yielded similar results. $(C)$ in vitro and in vivo activities of wild-type and mutant CED-3 proteins. Activities were scored as strong $(+++)$, intermediate $(++,+$, or $+/-$ ) or nondetectable $(-1$. CED-3(C358S) in vivo cell-killing activity was assessed on the basis of its ability to cause cell death in mechanosensory neurons in which it was expressed ectopically /S. Shaham and H.R. Horvitz, in prep.). Numbers in the two bottom rows indicate the average number of extra cells in the anterior pharynx of mutant animals and the number of animals scored, respectively. The number of extra cells reflects the in vivo cell-killing activity of a CED-3 protein. (N.A.) Not applicable.

ble protease activity (see below) to those of active mICE purified by Molineaux et al. (1993) using a similar truncated version of the ICE precursor but a different purification scheme (ligand affinity chromatography). However, we did not observe the $11-\mathrm{kD}$ polypeptide, an alternatively processed version of the $10-\mathrm{kD}$ polypeptide resulting from cleavage at Asp-308, and Molineaux et al. (1993) did not observe the $19.5-\mathrm{kD}$ polypeptide. Variations in either the preparation of bacterial lysates or in the purification protocols may be responsible for these differences in the purified proteases. The purified CPP32 protease preparation contained $17-$ and $12-\mathrm{kD}$ polypeptides that resulted from cleavage of full-length CPP32 protein at Asp-28 and Asp-175. This purified human CPP32 protease had identical subunit composition and comparable protease activity (see below) to those of active CPP32 protease purified from a human cell line using ligand affinity chromatography (Nicholson et al. 1995). These results concerning ICE and CPP32 indicate that our epitope-tag-mediated purification scheme, which circumvents the need for designing protease-specific ligands for affinity purification, is an effective method for purifying CED-3/ICE-like proteases.

Our purified CED-3 protease preparation contained polypeptides of 17,15 , and $13 \mathrm{kD}$, which resulted from cleavage of the full-length CED-3 protein at Asp-220, Asp-374, and Asp-388 (Fig. 3B). Purified human ICH-1 protease preparation contained polypeptides of 18,13 , and $12 \mathrm{kD}$, which resulted from cleavage of full-length ICH-1 protein at Asp-152, Asp-316, and Asp-330 (Fig. 3B). These data suggest that active CED-3 and ICH-1 proteases, like the ICE and CPP32 proteases, are likely to consist of heterodimeric complexes: CED-3 (p13/p17 or $\mathrm{p} 15 / \mathrm{p} 17\}$ and $\mathrm{ICH}-1$ (p12/p18 or p13/p18\}. Precursors of all of these proteases were processed exclusively after Asp residues and, in most cases, before a small amino acid such as Gly, Ala, or Ser (Fig. $3 \mathrm{C}$. These results confirmed that CED-3 and ICH-1 proteases, like ICE and CPP32 proteases, are aspartate-specific cysteine proteases (Howard et al. 1991; Thornberry et al. 1992; Nicholson et al. 1995).

\section{CED-3/ICE-like cysteine proteases have} different substrate specificities

We compared the substrate specificities of the four purified proteases discussed above and of the ICE-like pro- 
A

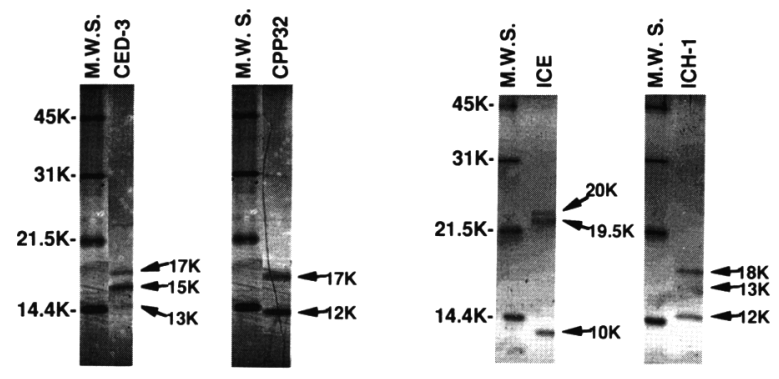

B

CED-3

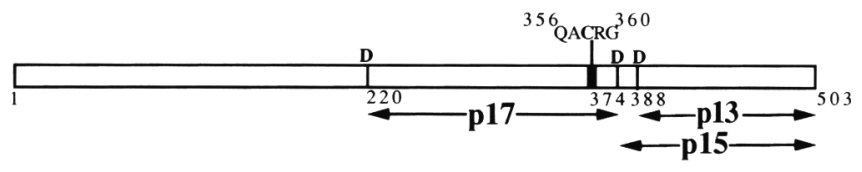

mICE

$\mathrm{ICH}-1$

CPP32
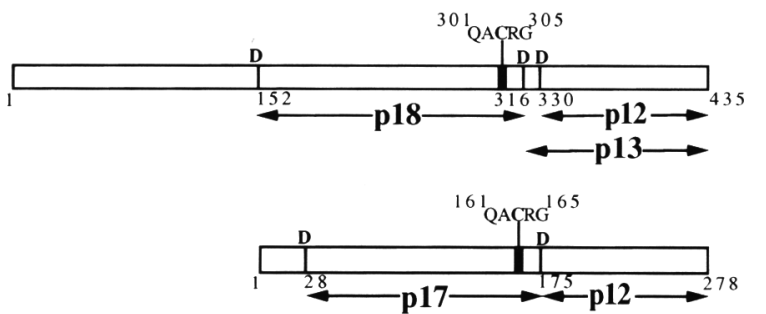

C

\section{Cleavage sites}

\begin{tabular}{|c|c|c|}
\hline \multirow{3}{*}{ CED-3 } & D220 & NFVDAPT \\
\hline & D374 & DSVDGVP \\
\hline & D388 & DNRDGPL \\
\hline \multirow{3}{*}{ mICE } & D122 & NKEDGTF \\
\hline & D296 & 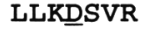 \\
\hline & D314 & FEDDIKK \\
\hline \multirow{3}{*}{ ICH-1 } & D152 & DNKDGPV \\
\hline & D316 & DQQDGKN \\
\hline & D330 & EESDAGK \\
\hline \multirow{2}{*}{ CPP32 } & D28 & ESMDSGI \\
\hline & D175 & IETDSGV \\
\hline
\end{tabular}

Figure 3. Subunit compositions of purified CED3, mICE, hICH-1, and hCPP32 proteases and their precursor cleavage sites. (A) Silver-stained gels of purified CED-3, mICE, hICH-l, and hCPP32 protease preparations (see Materials and methods). About $60 \mathrm{ng}$ of each purified CED-3, MICE, and hICH-l proteases or $300 \mathrm{ng}$ of purified hCPP32 protease was resolved on $15 \%$ SDS-Polyacrylamide gels and stained with $\mathrm{NH}_{4} \mathrm{NO}_{3} / \mathrm{AgNO}_{3}$ solution (Gottlieb and Chavko 1987). (M.W.S.) Protein molecular weight standards (silver stain SDSPAGE standards, low range; Bio-Radd). The size of each polypeptide is indicated. $(B)$ Diagram of the protease subunits and their relationships to the protease precursors. The size and the position of each protease subunit is depicted underneath the protease precursor. (D) Aspartate $r \epsilon$ sidue. Vertical lines underneath indicate proteclytic cleavage sites identified by microsequencing analysis and are numbered according to their positions in the protease precursors. The position of each conserved pentapeptide (QACRG) is numbered and indicated by a solid box. There is a methionine residue immediately preceding amino acid 118 of the truncated mICE precursor, which serves as the translation initiation codon fo:: mICE expression in E. coli. $(C)$ Identified cleavage sites in the protease precursors. The arrow at the bottom indicates the proteolytic cleavage sites. The Asp residues at the cleavage sites are underlined and numbered according to their positions in the protease precursors. The amino acid sequences around the Asp residues are shown. tease activity (prICE) present in concentrated extracts from chicken DU249 cells, which become committed to apoptosis as a result of a block during $\mathrm{S}$ phase induced by aphidocolin (Lazebnik et al. 1994). We used as potential substrates the four full-length protease precursors, the
IL- $1 \beta$ precursor protein (cleaved by ICE; Cerretti et al. 1992; Thornberry et al. 1992), baculovirus p35 protein (cleaved by CED-3/ICE-like cysteine proteases; Bump et al. 1995; Xue and Horvitz 1995), cowpox virus crmA protein (an ICE inhibitor and substrate; Ray et al. 1992; 
Xue et al.

Komiyama et al. 1994), and PARP (cleaved by prICE and CPP32; Kaufmann et al. 1993; Lazebnik et al. 1994; Nicholson et al. 1995; Tewari et al. 1995).

We synthesized and labeled these protein substrates in vitro with $\left[{ }^{35} \mathrm{~S}\right]$ methionine using rabbit reticulocyte lysates, incubated the labeled substrates with the five protease activities, and assessed the efficiency of substrate cleavage (Fig. 4; Table 1). Our analysis suggested that the five protease activities could be categorized into three groups based on their substrate specificities. The first group includes CED-3, CPP32, and prICE: All cleaved a common set of substrates efficiently to generate similar numbers and sizes of cleavage products /CED-3 and CPP32 precursors, baculovirus p35 protein, and PARP; Fig. 4 and Table 1; Xue and Horvitz 1995); and all failed to cleave or cleaved very poorly another set of substrates (ICE precursor, the Asp-116 cleavage site of the IL-1 $\beta$ precursor protein, and crmA; Fig. 4B,E,F; Table 1). The second group consists only of the ICE protease. ICE appeared to cleave every substrate we tested, although cleavage was inefficient, with the exception of crmA (Fig. 4; Table 1). The third group consists of the ICH-1 protease. The ICH-1 protease appeared to cleave only the ICH-1 precursor and the p35 protein under the condi-
A

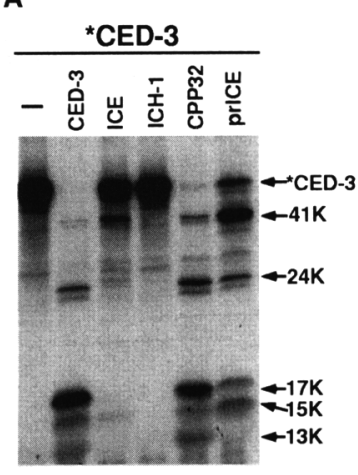

E

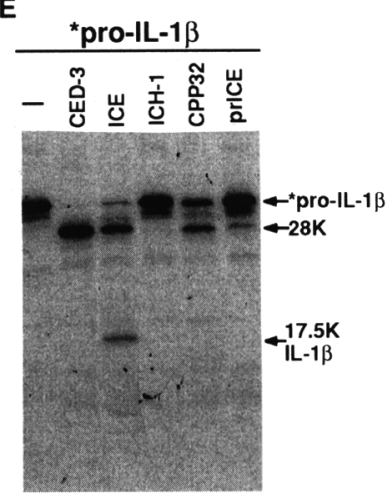

B

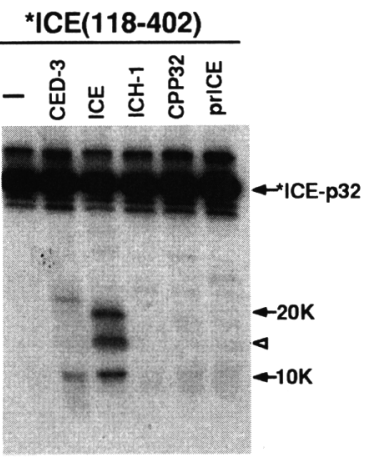

$\mathbf{F}$

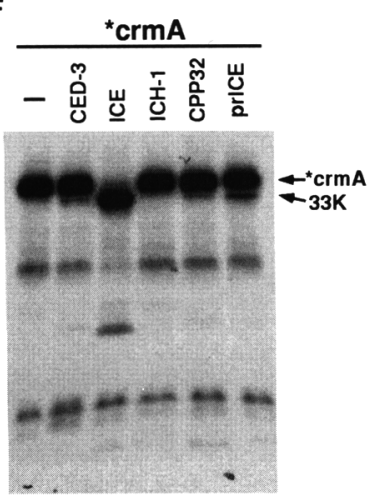

C

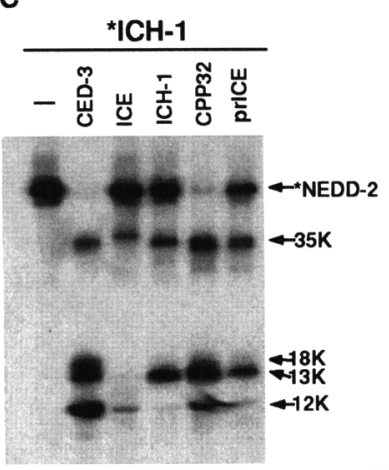

G

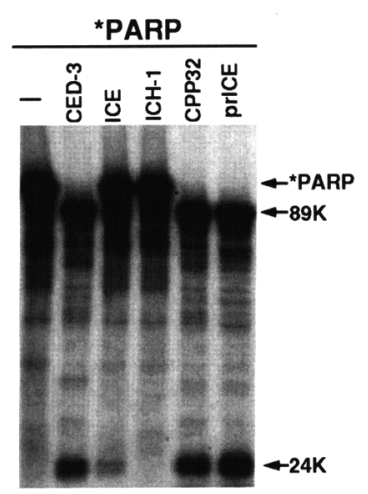

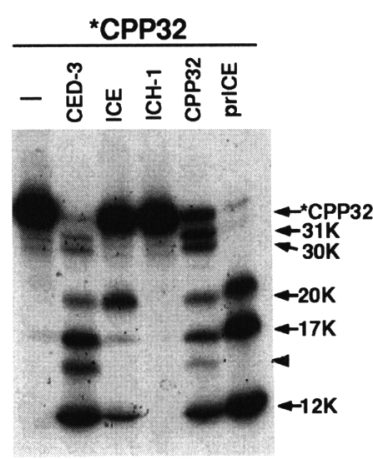

Figure 4. Substrate specificities of the purified cysteine proteases. Each $\left[{ }^{35} \mathrm{~S} /\right.$ methionine-labeled substrate $\left({ }^{*}\right)$ was incubated with 40 $\mathrm{ng}$ of a given purified protease or $1 \mu \mathrm{l}$ of chicken $\mathrm{S} / \mathrm{M}$ extract $(\mathrm{prICE})$ at $30^{\circ} \mathrm{C}$. Incubation times are indicated as follows: (Lanes 1$) 1$ $\mu \mathrm{l}$ of CED-3 buffer; (lanes 2) $1 \mu \mathrm{l}$ of CED-3 protease; (lanes 3) $1 \mu$ l of mouse ICE protease; (lanes 4) $1 \mu$ l of human ICH-1 protease; (lanes 5) $1 \mu \mathrm{l}$ of human CPP32 protease; (lanes 6) $1 \mu \mathrm{l}$ of chicken S/M extract (prICE). (A) ${ }^{35}$ S|Methionine-labeled full-length CED-3 protein $(1 \mathrm{hr})$. The cleavage products were identified as described for Fig. 1B. (B) ${ }^{35}$ S|Methionine-labeled murine ICE(118-402) precursor protein $(2 \mathrm{hr}$ ). The 20- and 10-kD bands may correspond to two mICE protease subunits (see Fig. 3). The band indicated by an open arrowhead may be an alternatively processed product. $(C)\left|{ }^{35} \mathrm{~S}\right|$ Methionine-labeled full-length human ICH-1 protein $(1 \mathrm{hr})$. The 18-, 13-, and $12-\mathrm{kD}$ bands may correspond to the three identified hICH-1 protease subunits (see Fig. 3). The $35-\mathrm{kD}$ band may be the aminoterminal cleavage product resulting from cleavage at Asp-316. (D) $\left|{ }^{35} \mathrm{~S}\right|$ Methionine-labeled full-length human CPP32 protein (1 hr). The 17 - and $12-\mathrm{kD}$ bands may correspond to two CPP32 protease subunits /see Fig. 3). The $20-\mathrm{kD}$ band may be the amino-terminal cleavage product resulting from cleavage at Asp-175. The $31-$ and $30-\mathrm{kD}$ bands may be the carboxy-terminal cleavage products resulting from cleavage at Asp-9 and Asp-28, respectively. The band indicated by an open arrowhead may be an alternatively processed product. $(E)$ $\left[{ }^{35} \mathrm{~S}\right]$ Methionine-labeled murine IL-1 $\beta$ precursor $(2 \mathrm{hr})$. The $28-\mathrm{kD}$ band may be the carboxy-terminal cleavage product resulting from cleavage at Asp-27. The $17.5-\mathrm{kD}$ band may be the mature IL-1 $\beta$, a carboxy-terminal cleavage product resulting from cleavage at Asp-116. $(F){ }^{35} \mathrm{~S}$ ) Methionine-labeled cowpox virus crmA protein $(1 \mathrm{hr})$. The $33-\mathrm{kD}$ band is the amino-terminal cleavage product resulting from cleavage at Asp-304. The 5-kD carboxy-terminal cleavage fragment was not seen here because it lacks methionine residues. $(G)\left[{ }^{35} \mathrm{~S}\right]$ Methionine-labeled human PARP protein $(1 \mathrm{hr})$. The 89 - and $24-\mathrm{kD}$ bands are the carboxy-and amino-terminal cleavage products resulting from cleavage at Asp-214, respectively. 
Table 1. Substrate specificities of the CED-3/ICE family proteases

\begin{tabular}{|c|c|c|c|c|c|c|c|c|c|}
\hline \multirow[b]{3}{*}{ Protease } & \multirow[b]{3}{*}{ CED-3 } & \multirow[b]{3}{*}{ mICE } & \multirow[b]{3}{*}{ hICH-1 } & \multirow[b]{3}{*}{ hСРP32 } & \multicolumn{5}{|c|}{ Substrate $^{\mathrm{a}}$} \\
\hline & & & & & & & \multirow[b]{2}{*}{$\mathrm{p} 35^{\mathrm{b}}$} & \multirow[b]{2}{*}{$\operatorname{crmA}$} & \multirow[b]{2}{*}{ PARP } \\
\hline & & & & & Asp-27 & Asp-116 & & & \\
\hline CED-3 & +++ & $+1-$ & +++ & ++ & +++ & - & +++ & - & +++7 \\
\hline hСРP32 & +++ & - & +++ & ++ & + & - & +++ & - & +++ \\
\hline prICE & ++ & - & + & +++ & $+1-$ & - & $++t$ & $+1-$ & +++ \\
\hline $\mathrm{mICE}$ & + & + & $+1-$ & + & ++ & ++ & ++ & +++ & +1 \\
\hline hICH-1 ${ }^{c}$ & - & - & ++ & - & - & - & + & - & -1 \\
\hline
\end{tabular}

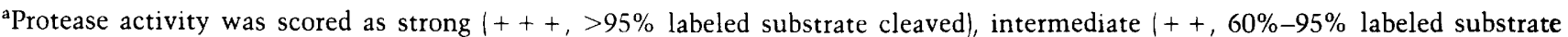
cleaved), weak $(+, 20 \%-60 \%$ labeled substrate cleaved), poor $(+1-, 10 \%-20 \%$ labeled substrate cleaved), and undetectable $(-,<10 \%$ labeled substrate cleaved). The extent of the cleavage of the labeled substrate was measured by PhosphorImaging analysis. The data presented for each substrate were compiled from at least two sets of independent experiments. For hIL-1 $\beta$, p35, crmA, and PARP, efficiency of cleavage at specific cleavage sites could be scored.

${ }^{b}$ Results are from Xue and Horvitz (1995).

'Substrates labeled - were not cleaved by an eightfold higher level of the hICH-l protease.

tions we tested (Fig. 4C; Table 1; Xue and Horvitz 1995). These differences in substrate preferences suggest that these cysteine proteases may act on different targets in vivo.

\section{Discussion}

Our demonstration that the CED-3 protein is a cysteine protease and that CED-3 cysteine protease activity appears to be required for CED-3 to cause programmed cell death in $C$. elegans strongly suggests that CED-3 functions in vivo as a cysteine protease, presumably by proteolytically activating a death-inducing protein or proteins and/or by proteolytically inactivating a death-preventing protein or proteins. Our in vitro assay for CED-3 function should provide an important approach for the analysis of the biochemical basis of programmed cell death, as effects of the protein components defined by the C. elegans genetic pathway for programmed cell death (for review, see Horvitz et al. 1994) can now be examined biochemically. For example, we can test whether genes that act genetically upstream of or parallel to ced-3 (such as ced-9 and ced-4; Hengartner et al. 1992; Shaham and Horvitz 1996) encode proteins that modulate CED-3 protease activity and whether genes that act genetically downstream of ced-3 (such as the ced genes involved in the engulfment of cell corpses; Ellis et al. 1991) encode proteins that are substrates for the CED-3 protease and that hence may be regulated by CED-3. Because the cell-death pathway is conserved between nematodes and mammals (for review, see Horvitz et al. 1994), such studies should provide important insights concerning the mechanisms of programmed cell death not only in C. elegans but also in other organisms, including humans. Our recent finding that the baculovirus $\mathrm{p} 35$ protein inhibits programmed cell death by inhibiting the CED-3 cysteine protease is an example of how such in vitro studies of CED-3 can reveal mecha- nisms that regulate programmed cell death (Xue and Horvitz 1995). The finding that CED-3 has similar substrate specificities to those of human CPP32 protease and chicken prICE suggests that the downstream target genes of these proteases may well be conserved.

Our method for purifying CED-3/ICE-like cysteine proteases using an epitope tag should be broadly helpful in studies of programmed cell death. This method, which could allow the isolation of any protein present in a protein complex with the tagged protease subunit, should be generally applicable for the purification of other members of the CED-3/ICE family and thereby for the studies of their biochemical properties and possible roles in programmed cell death. This method may also be useful for isolating proteins that associate with the protease complex and hence may modulate the activities of or act as substrates for such proteases (Bump et al. 1995).

Mutations in the ced-3 gene seem to prevent all programmed cell deaths in C. elegans (Ellis and Horvitz 1986), and to date no other member of the CED-3/ICE family has been identified in the worm. Thus, the CED-3 protease may mediate all programmed cell deaths that occur in this animal. In contrast, mammals contain multiple members of the CED-3/ICE family, each of which appears able to initiate apoptosis when overexpressed in mammalian cells (for review, see Martin and Green 1995). Which of these proteases, if any, is the mammalian functional equivalent of CED-3? We believe that the CPP32 protease is an excellent candidate, as CED-3 is much more similar to CPP32 in its substrate preferences than it is to ICE or ICH-1. For example, CPP32, CED-3, and prICE but not ICE and ICH-l (Figure 4G) cleave PARP efficiently (Table 1; Nicholson et al. 1995; Tewari et al. 1995), and PARP cleavage is an early event that occurs concomitantly with the onset of apoptosis (Kaufmann et al. 1993; Lazebnik et al. 1994). In addition, CED -3 is $34 \%$ identical to CPP 32 but only $28 \%$ identical to either ICE or ICH-1 in amino acid sequence 
(Fernandes-Alnemri et al. 1994; Kumar et al. 1994; Wang et al. 1994; Tewari et al. 1994; Nicholson et al. 1995). In particular, of the CED-3/ICE family cysteine proteases identified to date, only CED-3 and CPP32 are identical at the positions most critical in determining substrate specificity (amino acids equivalent to residues 342,343 , and 348 in hICE; Walker et al. 1994; Wilson et al. 1994; Nicholson et al. 1995). Furthermore, studies using peptide inhibitors and purified CPP32 and ICE proteases suggest that apoptotic events that occur in an in vitroreconstituted system involve a protease more like CPP32 than like ICE (Nicholson et al. 1995). These observations support the notion that CPP32 is a functional equivalent of CED-3 and, hence, is a protease involved directly in the execution of programmed cell death in mammals. However, CPP32 may not be the only CED$3 /$ ICE-like protease involved in programmed cell death in mammals. For example, the newly identified $\mathrm{MCH}-2$ and $\mathrm{MCH}-3$ proteins are similar to $\mathrm{CPP} 32$ in their primary sequences $(46 \%$ and $53 \%$ identities, respectively) and, like CPP32, are capable of cleaving PARP (Fernandes-Alnemri et al. 1995a,b|. MCH-2 and MCH-3 also may be good candidates for acting as cell-death proteases in mammals.

Two possible reasons that multiple CED-3/ICE-like proteases exist in mammals are that different cysteine proteases may act to cause the deaths of different cell types or that the deaths of some cell types may involve a cascade of such proteases. These possibilities are not mutually exclusive. We have observed that whereas ICE could process all four protease precursors we studied, albeit inefficiently, other proteases such as CPP32 and ICH-1 did not process the ICE precursor protein. These findings suggest that CPP32 and $\mathrm{ICH}-1$ probably do not directly activate ICE and raise the possibility that each might be activated by ICE. Tewari et al. (1995) demonstrated that ICE could activate CPP32 protease activity in vitro. We suggest that as a relatively inefficient and nonspecific CED-3/ICE family member, ICE might act as an initiator to activate more robust and specific proteases, such as CPP32, which then might amplify its own activities by cleaving other CPP32 precursor proteins. If ICE acts in this (or any) way to mediate apoptosis, other ICE-like activities must exist, as mice that lack ICE activity are not grossly defective in apoptosis (Kuida et al. 1995; Li et al. 1995).

The differences in substrate preferences among the three purified mammalian proteases we studied (ICE, $\mathrm{CPP} 32$, and $\mathrm{ICH}-1)$ suggest that these three proteases may have different in vivo targets and thus may play different roles in mediating cell death. We suggest that similar biochemical studies of additional CED-3/ICE family members, such as TX/ICH-2/ICE $\mathrm{Iel}_{\mathrm{II}}, \mathrm{MCH}-2$,

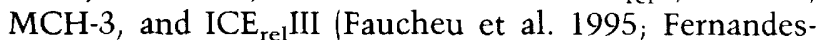
Alnemri et al. 1995a,b; Kamens et al. 1995; Munday et al. 1995), will provide important information about the functions of these proteases in mammalian apoptosis. Such studies combined with the analyses of mice in which single or multiple members of the CED-3/ICE protease family have been inactivated by mutation should help reveal how CED-3/ICE-like proteases act to execute programmed cell death in mammals.

\section{Materials and methods}

We followed standard molecular biology protocols, as described by Sambrook et al. (1989).

Construction of constructs for CED-3 expression in bacteria

We used the polymerase chain reaction (PCR) to amplify the full-length $\mathrm{CED}-3$ coding region with primers $5^{\prime}$-CAGGGATCCATGATGCGTCAA-3' and 5'-GTCGACGGATCCTACTTGTCATCGTCATCCTTGTAGTCGACGGCAGAGTTTCG-3', using pS126 (Shaham and Horvitz 1996), which contains a full-length ced-3 cDNA, as a DNA template. The latter primer contains a sequence for the FLAG epitope (DYKDDDDK/, which is fused to the carboxy terminus of CED-3. We digested the amplified product with $\mathrm{BamHI}$ and cloned the resulting fragment into the pBluescript $\mathrm{KS}$ | + vector (Stratagene) using its BamHI site. We synthesized single-stranded DNA from the resulting plasmid, $\mathrm{pDX} 2$, and used it to introduce specific CED-3 mutations according to the in vitro mutagenesis method of Kunkel (1985). We constructed pET-3a-CED-3FLAG and its mutant derivatives by cloning the Spel and SmaI fragment from $\mathrm{pDX} 2$ and its mutant derivatives into the pET-3a vector (Invitrogen) digested previously with Nhel and EcoRV.

Preparation of bacterial lysates expressing wild-type or mutant CED-3 proteins

The preparation of bacterial lysates expressing CED-3 proteins was essentially as described by Xue et al. (1993). Briefly, we diluted an overnight culture of $E$. coli BL21|DE3) carrying either pET-3a or CED-3 expression constructs 1:10 in $50 \mathrm{ml}$ of fresh LB broth supplemented with $75 \mu \mathrm{g} / \mathrm{ml}$ of ampicillin. We grew the cells at $37^{\circ} \mathrm{C}$ to an $A_{600}$ of 0.6 and induced the expression of CED-3 protein by adding isopropyl- $\beta$-D-thiogalactopyranoside (IPTG) to a final concentration of $1.0 \mathrm{~mm}$. We allowed the cells to grow for an additional $2 \mathrm{hr}$ at room temperature and then collected them by centrifugation at $3000 \mathrm{~g}$ for $5 \mathrm{~min}$. We resuspended the cells in $1 / 50$ volume of CED-3 buffer $(50 \mathrm{~mm}$ Tris$\mathrm{HCl}$ at $\mathrm{pH} 8.0,0.5 \mathrm{~mm}$ EDTA, $0.5 \mathrm{~mm}$ sucrose, $5 \%$ glycerol) supplemented with protease inhibitors $(1 \mathrm{~mm}$ PMSF, $5 \mu \mathrm{g} / \mathrm{ml}$ of aprotinin, $5 \mu \mathrm{g} / \mathrm{ml}$ of pepstatin, and $10 \mu \mathrm{g} / \mathrm{ml}$ of leupeptin). We lysed the cells by sonication and sedimented the debris by centrifugation at $14,000 \mathrm{~g}$ for $10 \mathrm{~min}$. We used the resulting supernatant, which we refer to as bacterial lysates, for Western blot analyses and for in vitro protease assays.

\section{Western blot analyses}

We subjected bacterial lysates to electrophoresis using 15\% SDS-PAGE, transferred the separated proteins to a nitrocellulose membrane, and probed this membrane with the mouse M2 monoclonal antibody (Eastman Kodak), which recognizes the FLAG epitope, using an ECL (Enhanced Chemiluminescence; Thorpe et al. 1984) Western blot kit following the instructions of the manufacturer (Amersham).

\section{In vitro protease assays}

For in vitro protease assays, we labeled CED-3 with $\left[{ }^{35} S \mid\right.$ methionine using the TNT-coupled reticulocyte lysate system (Promega) and $\mathrm{pDX} 2$ as a DNA template. We incubated $1 \mu \mathrm{l}$ of 
the translated reticulocyte lysate with $1 \mu \mathrm{l}$ of appropriately diluted bacterial lysates and $2 \mu \mathrm{l}$ of CED-3 buffer or $1 \mu l$ of CED-3 buffer and $1 \mu \mathrm{l}$ of a given inhibitor solution. The preparation of the inhibitors and the concentrations used were essentially as described by Nicholson et al. (1995). We terminated the reactions by adding an equal volume of SDS gel loading buffer and resolved the reactions using 15\% SDS-PAGE gels. The gels were dried and subjected to autoradiography.

\section{Construction of expression vectors for CED-3/ICE family members}

Construction of pET-3a-CED-3-FLAG-(His) ${ }_{6}$ was essentially as described above for pET-3a-CED-3-FLAG, except that the second primer was replaced by primer 5 '-CAAGGATCCTAGTGGTGGTGGTGGTGGTGC TTGTCAT CGTCATCCTTGTAGTCGACGGCAGAGTTTCG-3'. We constructed pET-3a-mICE(118-402)-FLAG by PCR amplification of the mICE coding region (amino acids 118-402) using primers 5'. GGACATATGAACAAAGAAGATGGCAC-3' and $5^{\prime}$-GAAGGGATCCTACTTGTCATCGTCATCCTTGTAGTCATGTCCCGGGAAGAGG-3', digestion of the amplified product with $\mathrm{NdeI}$ and $\mathrm{BamHI}$, and cloning of the resulting fragment into the pET-3a vector digested previously with NdeI and BamHI. We constructed pET-3a-hICH-1-FLAG by PCR amplification of the full-length human ICH-1 coding region with primers $55^{\prime}$-GGACATTAGGCCGCTGACAGGGGA-3' and 5'-GGACAGATCTACTTGTCATCGTCA TCCTTGT AGTCTGTGGGAGGGTGTCCTGG-3', digestion of the amplified products with NdeI and $B g I I I$, and cloning of the resulting fragment into the pET-3a vector digested previously with $\mathrm{NdeI}$ and $\mathrm{BamHI}$.

\section{Purification of cysteine proteases by epitope tagging}

The preparation of CED-3, ICE, ICH-1, and CPP32 bacterial lysates was as described above, except that 1 liter of each bacterial culture was grown. To purify the active CED-3 protease, we incubated $10 \mathrm{ml}$ of CED-3-FLAG-(His $)_{6}$ bacterial lysates with $1 \mathrm{ml}$ of $\mathrm{Ni}-\mathrm{NTA}\left(\mathrm{Ni}^{2+}\right.$-nitrilo-tri-acetic acid) resin (Qiagen) for $2 \mathrm{hr}$ at $4^{\circ} \mathrm{C}$. We washed the resin with 15 bed volumes of CED-3 buffer supplemented with $7.5 \mathrm{~mm} \beta$-mecaptoethanol, $0.4 \mathrm{M} \mathrm{NaCl}, 25 \mathrm{~mm}$ imidazole, and $0.04 \% \mathrm{NP}-40$ before eluting with four bed volumes of CED-3 buffer supplemented with 120 $\mathrm{mM}$ imidazole. To purify active mICE protease, we loaded $10 \mathrm{ml}$ of mICE-FLAG bacterial lysates onto a $6 \mathrm{ml} \mathrm{SP-Sepharose}$ (Pharmacia) column equilibrated previously with CED-3 buffer and eluted the proteins with a $20-\mathrm{ml}$ gradient of $0-0.5 \mathrm{M} \mathrm{NaCl}$ in CED-3 buffer. We pooled fractions eluted between 0.08 and $0.15 \mathrm{M} \mathrm{NaCl}$. These fractions contained most of the ICE protease activity. We incubated the pooled fractions with $0.2 \mathrm{ml}$ of anti-FLAG M2 affinity gel (Eastman Kodak) for $2 \mathrm{hr}$ at $4^{\circ} \mathrm{C}$. We washed the resin with 15 bed volumes of CED- 3 buffer supplemented with $0.6 \mathrm{M} \mathrm{NaCl}$ and $0.1 \% \mathrm{NP}-40$ before eluting with CED-3 buffer supplemented with $200 \mu \mathrm{g} / \mathrm{ml}$ of FLAG peptides. To purify the hICH-l protease, we loaded $10 \mathrm{ml}$ of hICH-1FLAG bacterial lysates onto an 8-ml Q-Sepharose (Pharmacia) column equilibrated previously with CED-3 buffer and eluted the proteins with an $80-\mathrm{ml} 0.05 \mathrm{M}$ step gradient of $\mathrm{NaCl}$ in CED-3 buffer (from $0 \mathrm{M}$ to $0.5 \mathrm{M} \mathrm{NaCl}$ ). We pooled fractions eluted at $0.25,0.30$, and $0.35 \mathrm{M} \mathrm{NaCl}$. These fractions contained most of the hICH-l protease activity. We incubated the pooled fractions with $0.2 \mathrm{ml}$ of anti-FLAG M2 affinity gel for $2 \mathrm{hr}$ at $4^{\circ} \mathrm{C}$. Elution of hICH-1-FLAG was done essentially as described for mICE-FLAG. The purification of CPP32, which was tagged with six histidine amino acids, was performed essentially as described for CED-3-FLAG-(His) ${ }_{6}$. We resolved the purified protease preparations using 15\% SDS-PAGE and stained the gels with the silver stain plus kit (Bio-Rad) following the instructions of the manufacturer.

\section{Microsequencing}

For microsequencing, we resolved $\sim 8 \mu \mathrm{g}$ of the purified CED-3, mICE, hICH-l, or hCPP32 protease preparations using $15 \%$ SDS-PAGE, transferred the separated polypeptides to a polyvinylidenedifluoride (PVDF) membrane, and stained the mem brane with Coomassie blue. We cut out regions of the membrane containing polypeptide bands of interest and subjected them to six cycles of protein microsequencing (Hunkapiller and Hood 1983!.

\section{Comparison of the substrate specificities of the CED-3/ICE} cysteine proteases

We excised from plasmid pL15TK (Kupper et al. 1990) a SacI$X b a I$ fragment that contains a full-length human PARP cDNA and cloned this fragment into the SacI-XbaI sites of pBluescript $\mathrm{KS}|+|$ |Stratagenel. We call the resulting plasmid $\mathrm{pKS} \mid+1-$ hPARP. We excised from plasmid pHST200 (Gehrke et al. 1990) a PstI-BamHI fragment that contains a full-length human IL-1 $\beta$ precursor cDNA and cloned this fragment into the PstI-BamHI sites of pBluescript $\mathrm{KS}(+)$. We call the resulting plasmid pKS $1+1$-hpreIL-1 $\beta$. We used the following DNA templates to synthesize $\left.\right|^{35} \mathrm{~S} \mid$ methionine-labeled protein substrates using TNT lysates as described above: (1) CED-3-pDX2; $(2)$ hICH-1pET-3a-hICH-1-FLAG; (3) mICE (118-402) precursor-pET-3amICE(118-402)-FLAG; (4) hCPP32-pET-21b-hCPP32-(His) ${ }_{6}$; (5) hIL-1 $\beta$ precursor-pKS + -hpreIL-1 $\beta$; 6) crmA-pDX10 (Xue and Horvitz 1995); and (7) PARP-pKS|+ -hPARP. We incubated $1 \mu \mathrm{l}$ of the translated reticulocyte lysate with $40 \mathrm{ng}$ of a given purified protease and $2 \mu \mathrm{l}$ of CED-3 buffer at $30^{\circ} \mathrm{C}$.

\section{Acknowledgments}

We thank Monica Driscoll, Sander van den Heuvel, Hitoshi Sawa, and Zheng Zhou for discussions and comments concerning this manuscript; Junying Yuan for providing cDNAs encoding mICE, hICH-l, and cowpox virus crmA; Yuri Lazebnik for chicken S/M extract; Lee Gehrke for a cDNA-encoding human IL-1 $\beta$ precursor; Serge Desnoyers and Guy G. Poirier for a cDNA-encoding hPARP; and the MIT Biopolymers Laboratory for performing the microsequencing analysis. D.X. was supported by postdoctoral fellowships from the Anna Fuller Fund and the Helen Hay Whitney Foundation. S.S. was supported by a research fellowship from Glaxo Research Institute. H.R.H. is an Investigator of the Howard Hughes Medical Institute.

The publication costs of this article were defrayed in part by payment of page charges. This article must therefore be hereby marked "advertisement" in accordance with 18 USC section 1734 solely to indicate this fact.

\section{References}

Bump, N.J., M. Hackett, M. Hugunin, S. Seshagiri, K. Brady, P. Chen, C. Ferenz, S. Franklin, T. Ghayur, P. Li, P. Licari, J. Mankovich, L. Shi, A.H. Greenberg, L.K. Miller, and W.W. Wong. 1995. Inhibition of ICE family proteases by baculovirus antiapoptotic protein p35. Science 269: 1885-1888.

Cerretti, D.P., C.J. Kozlosky, B. Mosley, N. Nelson, N. Ness, T.A. Greenstreet, C.J. March, S.R. Kronheim, T. Druk, L.A. Cannizzaro, K. Huebner, and R.A. Black. 1992. Molecular 
cloning of the interleukin-1 $\beta$-converting enzyme. Science 256: $97-100$.

Clem, R.J., M. Fechheimer, and L.K. Miller. 1991. Prevention of apoptosis by a baculovirus gene during infection of insect cells. Science 254: 1388-1390.

Ellis, H.M. and H.R. Horvitz. 1986. Genetic control of programmed cell death in the nematode C. elegans. Cell 44: 817-829.

Ellis, R.E., J. Yuan, and H.R. Horvitz. 1991. Mechanisms and functions of cell death. Annu. Rev. Cell Biol. 7: 663-698.

Faucheu, C., A. Diu, A.W. Chan, A.M. Blanchet, C. Miossec, F. Herve, V. Collard-Dutilleul, Y. Gu, R.A. Aldape, J.A. Lippke, C. Rocher, M.S.S. Su, D.J. Livingston, T. Hercend, and J.L. Lalanne. 1995. A novel human protease similar to the interleukin-1 $\beta$-converting enzyme induces apoptosis in transfected cells. $E M B O$ J. 14: 1914-1922.

Fernandes-Alnemri, T., G. Litwack, and E.S. Alnemri. 1994. CPP32, a novel human apoptotic protein with homology to Caenorhabditis elegans cell death protein CED-3 and mammalian interleukin-1 $\beta$-converting enzyme. I. Biol. Chem. 269: 30761-30764.

1995a. Mch2, a new member of the apoptotic ced-3/Ice cysteine protease gene family. Cancer Res. 55: 2737-2742.

Fernandes-Alnemri, T., A. Takahashi, R. Armstrong, J. Krebs, L. Fritz, K.J. Tomaselli, L. Wang, Z. Yu, C.M. Croce, G. Salveson, W. Earnshaw, G. Litwack, and E.S. Alnemri. 1995b. $M c h 3$, a novel human apoptotic cysteine protease highly related to cpp32. Cancer Res. 55: 6045-6052.

Gehrke, L., S.A. Jobling, L.S. Paik, B. McDonald, L.J. Rosenwasser, and P.E. Auron. 1990. A point mutation uncouples human interleukin-1 $\beta$ biological activity and receptor binding. J. Biol. Chem. 265: 5922-5925.

Gottlieb, M. and M. Chavko. 1987. Silver staining of native and denatured eucaryotic DNA in agarose gels. Anal. Biochem. 165: 33-37.

Hay, B.A., T. Wolff, and G.M. Rubin. 1994. Expression of baculovirus p35 prevents cell death in Drosophila. Development 120: 2121-2129.

Hengartner, M.O., R.E. Ellis, and H.R. Horvitz. 1992. Caenorhabditis elegans gene ced-9 protects cells from programmed cell death. Nature 356: 494-499.

Hopp, T.P., K.S. Prickett, V. Price, R.T. Libby, C.J. March, P. Cerretti, D.L. Urdal, and P.J. Conlon. 1988. A short polypeptide marker sequence useful for recombinant protein identification and purification. Biotechnology 6: 1205-1210.

Horvitz, H.R., S. Shaham, and M.O. Hengartner. 1994. The genetics of programmed cell death in the nematode Caenorhabditis elegans. Cold Spring Harbor Symp. Quant. Biol. 27: 377-385.

Howard, A.D., M.J. Kostura, N. Thornberry, G.J. Ding, G. Limjuco, J. Weidner, J.P. Salley, K.A. Hogquist, D.D. Chaplin, R.A. Mumford, J.A. Schmidt, and M.J. Tocci. 1991. IL-1Bconverting enzyme requires aspartic acid residues for processing of the IL-1 $\beta$ precursor at two distinct sites and does not cleave 31-kD IL-l $\alpha$. I. Immunol. 147: 2964-2969.

Hugunin, M., L.J. Quintal, J. A. Mankovich, and T. Ghayur. 1996. Protease activity of in vitro transcribed and translated Caenorhabditis elegans cell death gene (ced-3) product. I. Biol. Chem. 271: 3517-3522.

Hunkapiller, M.W. and L.E. Hood. 1983. Protein sequence analysis: Automated microsequencing. Science 219: 650-659.

Kamens, J., M. Paskind, M. Hugunin, R.V. Talanian, H. Allen, D. Banach, N. Bump, M. Hackett, C.G. Johnston, P. Li, J.A. Mankovich, M. Terranova, and T. Ghayur. 1995. Identification and characterization of $\mathrm{ICH}-2$, a novel member of the interleukin-1 $\beta$-converting enzyme family of cysteine pro- teases. I. Biol. Chem. 270: 15250-15256.

Kamita, S.G., K. Majima, and S. Maeda. 1993. Identification and characterization of the p35 gene of Bombyx mori nuclear polyhedrosis virus that prevents virus-induced apoptosis. $I$. Virol. 67: 455-463.

Kaufmann, S.H., S. Desnoyers, Y. Ottaviano, N.E. Davidson, and G.G. Poirier. 1993. Specific proteolytic cleavage of poly (ADP-ribose) polymerase: An early marker of chemotherapyinduced apoptosis. Cancer Res. 53: 3976-3985.

Komiyama, T., C.A. Ray, D.J. Pickup, A.D. Howard, N.A. Thornberry, E.P. Peterson, and G. Salvesen. 1994. Inhibition of interleukin-1 $\beta$-converting enzyme by the cowpox virus serpin CrmA: An example of cross-class inhibition. I. Biol. Chem. 269: 19331-19337.

Kuida, K., J.A. Lippke, G. Ku, M.W. Harding, D.J. Livingston, M.S. Su, and R.A. Flavell. 1995. Altered cytokine export and apoptosis in mice deficient in interleukin-1 $\beta$-converting enzyme. Science 267: 2000-2003.

Kumar, S., M. Kinoshita, M. Noda, N.G. Copeland, and N.A. Jenkins. 1994. Induction of apoptosis by the mouse Nedd2 gene, which encodes a protein similar to the product of the Caenorhabditis elegans cell death gene ced-3 and the mammalian IL-1 $\beta$-converting enzyme. Genes \& Dev. 8: 16131626.

Kunkel, T.A. 1985. Rapid and efficient site-specific mutagenesis without phenotypic selection. Proc. Natl. Acad. Sci. 82: $488-492$

Kupper, J.H., G. de Murcia, and A. Burkle. 1990. Inhibition of poly (ADP-ribosyllation by overexpressing the poly (ADPribosel polymerase DNA-binding domain in mammalian cells. I. Biol. Chem. 265: 18721-18724.

Lazebnik, Y.A., S.H. Kaufmann, S. Desnoyers, G.G. Poirier, and W.C. Earnshaw. 1994. Cleavage of poly(ADP-ribose) polymerase by a proteinase with properties like ICE. Nature 371: 346-347.

Li, P., H. Allen, S. Baneriee, S. Franklin, L. Herzog, C. Johnston, J. McDowell, M. Paskind, L. Rodman, J. Salfeld, E. Towne, D. Tracey, S. Wardwell, F.Y. Wei, W.W. Wong, R. Kamen, and T. Seshadri. 1995. Mice deficient in IL-1 $\beta$-converting enzyme are defective in production of mature IL- $1 \beta$ and resistant to endotoxic shock. Cell 80: 401-411.

Martin, S.J. and D. Green. 1995. Protease activation during apoptosis: Death by a thousand cuts? Cell 82: 349-352.

Molineaux, S.M., F.J. Casano, A.M. Rolando, E.P. Peterson, G. Limjuco, J. Chin, P.R. Griffin, J.R. Calaycay, G.J. Ding, T.T Yamin, C.P. Oksana, S. Luell, D. Fletcher, D.K. Miller, A.D. Horward, N.A. Thornberry, and M.J. Kostura. 1993. Interleukin- $1 \beta$ (IL- 1 beta) processing in murine macrophages requires a structurally conserved homologue of human IL-1 $\beta$ converting enzyme. Proc. Natl. Acad. Sci. 90: 1809-1813.

Munday, N.A., J.P. Vaillancourt, A. Ali, F.J. Casano, D.K. Miller, S.M. Molineaux, T.T. Yamin, V.L. Yu, and D.W. Nicholson. 1995. Molecular cloning and pro-apoptotic activity of ICE $\mathrm{rel}_{\mathrm{rl}}$ and ICE $\mathrm{rel}_{\mathrm{rel}} \mathrm{II}$, members of the ICE/CED-3 family of cysteine proteases. J. Biol. Chem. 270: 15870-15876.

Nicholson, D.W., A. Ali, N.A. Thornberry, J.P. Vaillancourt, C.K. Ding, M. Gallant, Y. Gareau, P.R. Griffin, M. Labelle, Y.A. Lazebnik, N.A. Munday, S.M. Raju, M.E. Smulson, T.T. Yamin, V.L. Yu, and D.K. Miller. 1995. Identification and inhibition of the ICE/CED-3 protease necessary for mammalian apoptosis. Nature 376: $37-43$.

Oltvai, Z.N. and S.J. Korsmeyer. 1994. Checkpoints of dueling dimers foil death wishes. Cell 79: 189-192.

Rabizadeh, S., D.J. LaCount, P.D. Friesen, and D.E. Bredesen. 1993. Expression of the baculovirus p35 gene inhibits mammalian neural cell death. I. Neurochem. 61: 2318-2321 
Ray, C.A., R.A. Black, S.R. Kronheim, T.A. Greenstreet, P.R. Sleath, G.S. Salvesen, and D.J. Pickup. 1992. Viral inhibition of inflammation: Cowpox virus encodes an inhibitor of the interleukin-1 $\beta$-converting enzyme. Cell 69: 597-604.

Sambrook, J., E.F. Fritsch, and T. Maniatis. 1989. Molecular cloning: A laboratory manual, 2nd ed. Cold Spring Harbor Laboratory Press, Cold Spring Harbor, NY.

Shaham, S. and H.R. Horvitz. 1996. Developing Caenorhabditis elegans neurons may contain both cell-death protective and killer activities. Genes \& Dev. 10: 578-591.

Steller, H. 1995. Mechanisms and genes of cellular suicide. Science 267: 1445-1449.

Studier, F.W., A.H. Rosenberg, J.J. Dunn, and J.W. Dubendorff. 1990. Use of T7 RNA polymerase to direct expression of cloned genes. Methods Enzymol. 185: 60-89.

Sugimoto, A., P.D. Friesen, and J.H. Rothman. 1994. Baculovirus p35 prevents developmentally programmed cell death and rescues a ced-9 mutant in the nematode Caenorhabditis elegans. EMBO I. 13: 2023-2028.

Tewari, M., L.T. Quan, K. O'Rourke, S. Desnoyers, Z. Zeng, D.R. Beidler, G.G. Poirier, G.S. Salvesen, and V.M. Dixit. 1995. Yama/CPP32 $\beta$, a mammalian homolog of CED-3, is a crmA-inhibitable protease that cleaves the death substrate poly(ADP-ribose) polymerase. Cell 81: 801-809.

Thompson, C.B. 1995. Apoptosis in the pathogenesis and treatment of disease. Science 267: 1456-1462.

Thornberry, N.A., H.G. Bull, J.R. Calaycay, K.T. Chapman, A.D. Howard, M.J. Kostura, D.K. Miller, S.M. Molineaux, J.R. Weidner, J. Aunins, T.D. Lee, J.E. Shively, M. MacCross, R.A. Mumford, J.A. Schmidt, and M.J. Tocci. 1992. A novel heterodimeric cysteine protease is required for interleukin$1 \beta$ processing in monocytes. Nature 356: 768-774.

Thorpe, G.H., R. Haggart, L.J. Kricka, and T.P. Whitehead. 1984. Enhanced luminescent enzyme immunoassays for rubella antibody, immunoglobulin $\mathrm{E}$ and digoxin. Biochem. Biophys. Res. Commun. 119: 481-487.

Walker, N.P., R.V. Talanian, K.D. Brady, L.C. Dang, N.J. Bump, C.R. Ferenz, S. Franklin, T. Ghayur, M.C. Hackett, L.D. Hammill, L. Herzog, M. Hugunin, W. Houy, J.A. Mankovich, L.M. McGuiness, E. Orlewicz, M. Paskind, C.A. Pratt, P. Reis, A. Summani, M. Terranova, J.P. Welch, L. Xiong, A. Moller, D.E. Tracey, R. Kamen, and W.W. Wong. 1994. Crystal structure of the cysteine protease interleukin- $1 \beta$-converting enzyme: A $(\mathrm{p} 20 / \mathrm{p} 10)_{2}$ homodimer. Cell 78: 343-352.

Wang, L., M. Miura, L. Bergeron, H. Zhu, and J. Yuan. 1994. Ich-1, an Ice/ced-3-related gene, encodes both positive and negative regulators of programmed cell death. Cell 78: 739750.

Wilson, K.P., J.A. Black, J.A. Thomson, E.E. Kim, J.P. Griffith, M.A. Navia, M.A. Murcko, S.P. Chambers, R.A. Aldape, S.A. Raybuck, and D.J. Livingston. 1994. Structure and mechanism of interleukin-1 $\beta$-converting enzyme. Nature $\mathbf{3 7 0}$ : 270-275.

Xue, D. and H.R. Horvitz. 1995. Inhibition of the Caenorhabditis elegans cell-death protease CED-3 by a CED-3 cleavage site in baculovirus p35 protein. Nature 377: 248-251.

Xue, D., Y. Tu, and M. Chalfie. 1993. Cooperative interaction between the C. elegans homeoproteins UNC-86 and MEC-3. Science 261: 1324-1328.

Yuan, J. and H.R. Horvitz. 1992. The Caenorhabditis elegans cell death gene ced-4 encodes a novel protein and is expressed during the period of extensive programmed cell death. Development 116: 309-320.

Yuan, J., S. Shaham, S. Ledoux, H.M. Ellis, and H.R. Horvitz. 1993. The C. elegans cell death gene ced-3 encodes a protein similar to mammalian interleukin- $\beta$-converting enzyme. Cell 75: 641-652. 


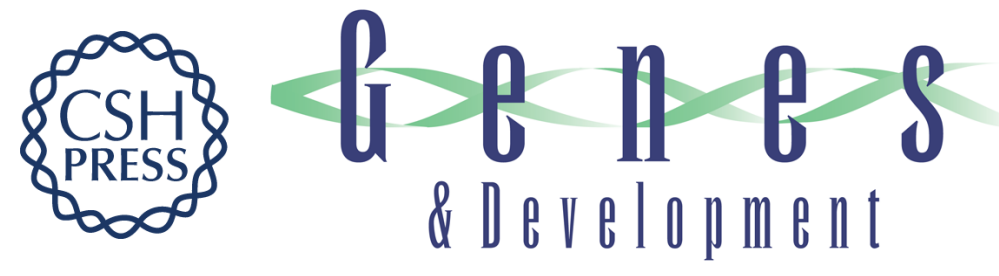

\section{The Caenorhabditis elegans cell-death protein CED-3 is a cysteine protease with substrate specificities similar to those of the human CPP32 protease.}

D Xue, S Shaham and H R Horvitz

Genes Dev. 1996, 10:

Access the most recent version at doi:10.1101/gad.10.9.1073

References This article cites 50 articles, 26 of which can be accessed free at:

http://genesdev.cshlp.org/content/10/9/1073.full.html\#ref-list-1

License

Email Alerting Service

Receive free email alerts when new articles cite this article - sign up in the box at the top right corner of the article or click here.

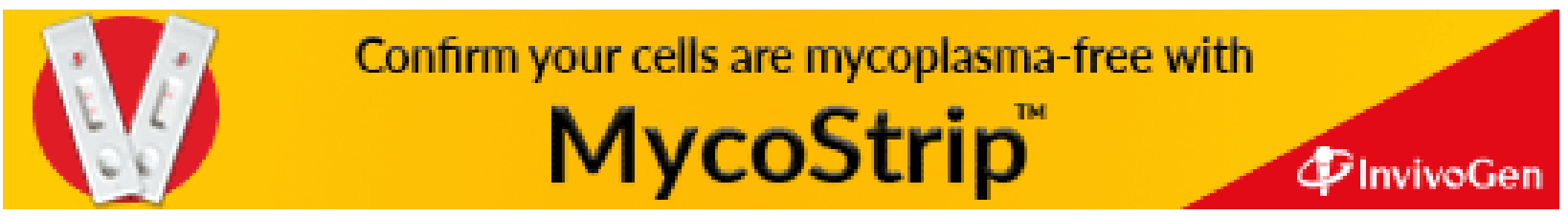

